\title{
Professional income tax: types of activities, rates, application criteria
}

\author{
Tatyana Zyryanova ${ }^{1}$, Elena Manakova ${ }^{2, *}$, Sergey Zyryanov ${ }^{1}$, and Gulnara Dyuzelbayeva ${ }^{3}$ \\ ${ }^{1}$ Urals state agrarian university, 620075, Karl Liebknecht Str., 42, Ekaterinburg, Russia \\ ${ }^{2}$ Russian Presidential Academy of National Economy and Public Administration, 620144, March 8 \\ Str., 66, Ekaterinburg, Russia \\ ${ }^{3}$ Kostanay Engineering and Economics University named after M. Dulatov, 110007, 59 \\ Chernyshevsky street, Kostanay, Kazakhstan
}

\begin{abstract}
In the context of rising unemployment due to the difficult economic situation that has arisen in connection with the coronavirus pandemic, citizens ' interest in the tax for the self-employed has increased. The article shows the reasons for the growing interest of citizens in the professional income tax (hereinafter - the PIT). As of 1 January 2019, a new experimental tax regime was introduced in four regions of Russia, and from July 1, 2020 all regions of Russia can introduce this tax regime. The main criteria for applying the professional income tax are considered. Determination of the place of business, rates, as well as benefits provided for by current legislation. Tax risks and advantages of working with selfemployed organizations. Conditions established by regulations for the application of PITs. Features of the transition to the new regime of individual entrepreneurs. An algorithm for checking risks by the internal controller when working with the self-employed is proposed.
\end{abstract}

\section{Introduction}

Changes to tax legislation are made quite often and one of the tasks of the internal controller is the need to track tax innovations. Considering tax changes, the internal controller helps not only reduce tax risks and, as a result, avoid penalties, but also offers the organization's management legitimate optimize taxes.

All methods of tax minimization are divided into two separate categories: illegal tax evasion and legal reduction of tax payments or legitimate tax reduction [1]. Accordingly, the main difference between these categories is that the taxpayer violates the current legislation or acts within the framework of the norms of laws (table 1).

Table 1. Main differences between legal tax cuts (tax optimization) and tax evasion

\begin{tabular}{|c|c|c|}
\hline $\begin{array}{c}\text { Actions of taxpayers to } \\
\text { minimize the tax burden }\end{array}$ & Tax optimization & Tax evasion \\
\hline The nature of the action & $\begin{array}{c}\text { The controlling state bodies } \\
\text { recognize the taxpayer's actions as } \\
\text { lawful }\end{array}$ & $\begin{array}{c}\text { Controlling state bodies classify } \\
\text { the taxpayer's actions as illegal }\end{array}$ \\
\hline $\begin{array}{c}\text { Nature of the methods } \\
\text { used }\end{array}$ & $\begin{array}{c}\text { The taxpayer uses legal methods } \\
\text { to reduce tax payments to }\end{array}$ & $\begin{array}{c}\text { The taxpayer uses illegal ways } \\
\text { to reduce tax payments to }\end{array}$ \\
\hline
\end{tabular}

* Corresponding author: manakova.elena@inbox.ru 


\begin{tabular}{|c|c|c|}
\hline $\begin{array}{c}\text { The nature of the } \\
\text { taxpayer's liability for } \\
\text { the methods used by the } \\
\text { taxpayer }\end{array}$ & $\begin{array}{c}\text { The responsibility of the taxpayer } \\
\text { for acts committed the purpose of } \\
\text { minimizing the tax burden is not } \\
\text { provided }\end{array}$ & $\begin{array}{c}\text { The taxpayer bear administrative } \\
\text { and criminal responsibility for } \\
\text { his actions committed in order to } \\
\text { minimize the tax burden }\end{array}$ \\
\hline
\end{tabular}

\section{Method}

The internal controller to prevent illegal minimization of taxes (fees) must take into account not only the norms of the current legislation, but also the judicial practice and explanations of the controlling authorities.

Notice however that the organization's management sets the internal controller the task of minimizing the tax burden with timely consideration of changes made to the current legislation.

Leaders' attention a new tax for self-employed citizens, a tax on professional income (PIT), which organizations began to use to optimize their tax burden since 2019 [2].

Since 2020, the regime has been operating in 23 regions, and since July 01, 2020, the subjects of the Russian Federation, which not included in the experiment to establish the NAP regime, have been granted the right to establish this regime on their territory $[3,4]$.

The number of self-employed in the first half of the year increased by 10,5 times compared to the same period last year [5].

According to experts, the reasons for the growth of the self-employed can be specified as follows [5]:

- rising unemployment;

- due to the loss of their jobs, some citizens rethought their employment and began to engage in activities that used to be a hobby;

- many were forced to register as self-employed at the request of the employer.

Note the main conclusions of the work of organizations with the self-employed:

- in cooperation working with the self-employed, they do not need to pay insurance premiums and personal income tax in the amount of $13 \%$, which are paid if the organization works with an individual under a civil contract or an employment contract;

- the possibility of reducing the tax base on income tax by the amount paid to registered as self-employed;

- lack of staff records;

- there is no need to submit reports for the self-employed to the pension Fund, which reduces the labor costs of the bookkeeping.

However, in order to reduce the tax risks that organizations may face when working with self-employed, internal controllers should study the intricacies of tax legislation when applying the PIT.

\section{Study detail and result}

So, PITs can be paid by citizens who have registered as PIT payers (self-employed) or individual entrepreneurs who have switched from the previously used system as selfemployed.

Self-employed can not accept employees, and also do not have the right to act as employers under the GPH contract. Self-employed receive their income from personal work. Citizens who use PIT, can't conduct business using other tax regimes. 2).

Let's consider the criteria that are defined in the Law that allow applying the PIT (Table 
Table 2. Main criteria for the application of NAPs established in the tax code of the Russian Federation

\begin{tabular}{|c|l|}
\hline Designation & \multicolumn{1}{|c|}{ Conducting entrepreneurial activity by the self-employed } \\
\hline Taxpayers & $\begin{array}{l}\text { - individual entrepreneurs; } \\
\text { - physical entities }\end{array}$ \\
\hline Registration & $\begin{array}{l}\text { don't need to visit the tax office. For registration, they use the } \\
\text { mobile application "My tax" }\end{array}$ \\
\hline Restrictions for use & $\begin{array}{l}\text { - income - 2,4 million rub.; } \\
\text { - employees cannot be accepted under employment contracts; } \\
\text { - a circle of persons who are not allowed to use this special } \\
\text { regime; }\end{array}$ \\
$\begin{array}{c}\text { - when conducting activities related to PITs, must not have an } \\
\text { employer }\end{array}$ \\
\hline $\begin{array}{c}\text { Exemption from taxes, } \\
\text { contributions }\end{array}$ & $\begin{array}{l}\text { physical entities: } \\
\text { - personal income tax for PIT income } \\
\text { individual entrepreneurs: } \\
\text { - VAT; insurance premium }\end{array}$ \\
\hline Taxable objects & income from independent activities \\
\hline Taxation & $\begin{array}{l}4 \% \text { rate (reduced to 3\% when applying a tax deduction), } \% \\
\text { rate (reduced to 4\%) }\end{array}$ \\
\hline Tax deduction & in the amount of 10,000 rub. \\
\hline Payment of taxes & $\begin{array}{l}\text { the tax is calculated automatically in the mobile app. Payment } \\
\text { no later than the } 25 \text { th day of the following month }\end{array}$ \\
\hline $\begin{array}{c}\text { Generation of reporting } \\
\text { documents (checks) }\end{array}$ & $\begin{array}{l}\text { don't need an online sales register to work. The receipt is } \\
\text { generated in the mobile application "My tax" }\end{array}$ \\
\hline Accounting & do not submit \\
\hline
\end{tabular}

Table 3 shows the types of activities that are allowed and prohibited to operate under the PIT.

Table 3. Types of activities for which the NAP is allowed and prohibited

\begin{tabular}{|l|l|}
\hline Activities whose revenues are subject to PITs & $\begin{array}{l}\text { The legislator does not give the opportunity to } \\
\text { apply this status to those who }\end{array}$ \\
\hline -providing cosmetic services at home & -sell excisable and marked goods; \\
-photo and video shooting to order & -are engaged in the resale of goods; \\
-sales of own-made products & -conduct intermediary activities; \\
-holding events and holidays & -extract or sell mineral resources; \\
-legal advice and accounting & -deliver goods with accepting payments in favor \\
-remote work via electronic platforms & of others; \\
-renting an apartment for daily or longterm & -apply other taxation regimes; \\
rent & -conduct entrepreneurial activities subject to \\
-passenger and cargo transportation services & personal income tax \\
-construction and renovation of premises & \\
\hline
\end{tabular}

Since the law does not specify a clear list of activities for which PITs can be paid, for example, when taxpayers (self-employed) are subject to a special tax regime, farms (representatives of the agro-industrial complex) that produce and sell products of their own production.

In fact, foreign citizens, in particular citizens of Belarus, Armenia, Kazakhstan and Kyrgyzstan, can also be self-employed, in addition to Russian citizens.

The place of activity, when switching to the PIT, is the location of the taxpayer when carrying out activities and the individual independently indicates the subject of the Russian Federation, on the territory of which the activity is conducted.

Determining the place of business is a complex issue. In particular, if the work is carried out remotely, the place of business is determined by the taxpayer's choice: 
- or at the location of the taxpayer's PIT;

- or at the location of the buyer or custome $[6,7]$.

When conducting business on the territories of several subjects of the Russian Federation, the self-employed person has the right to choose the subject independently, on the territory of which the activity is conducted. The place of business can only be changed once per calendar year.

The PIT is calculated in the following order

$\mathrm{ND}=$ Prof Income * Rate,

where ProfIncom - income received by the self-employed during the tax period;

Rate - the tax rate.

The tax rate depends on whether the self-employed person works with physical entities or legal entities (Fig. 1).

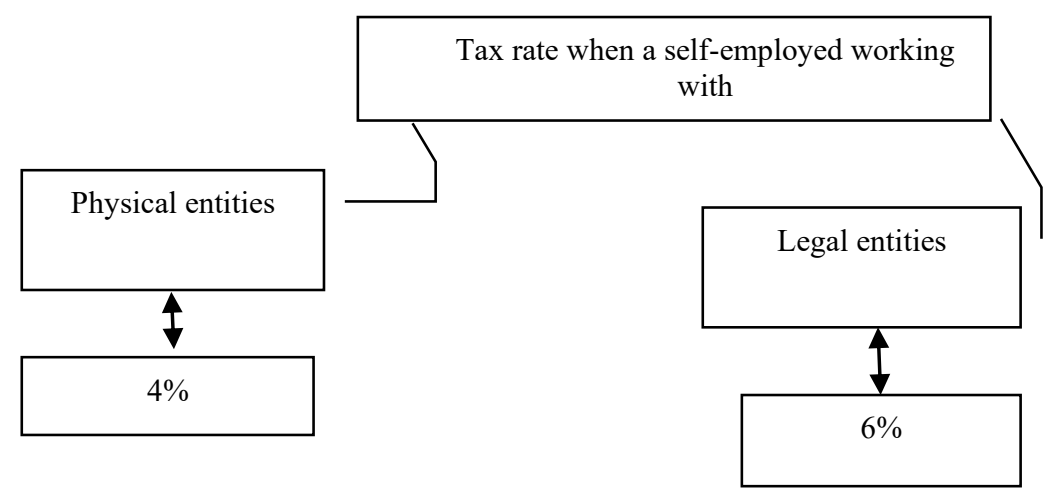

Fig. 1. Tax Rates for calculating PITs

When calculating the tax, the PIT payer can use the tax deduction, which is provided once. The figure shows typical situations of applying the deduction (Fig. 2)

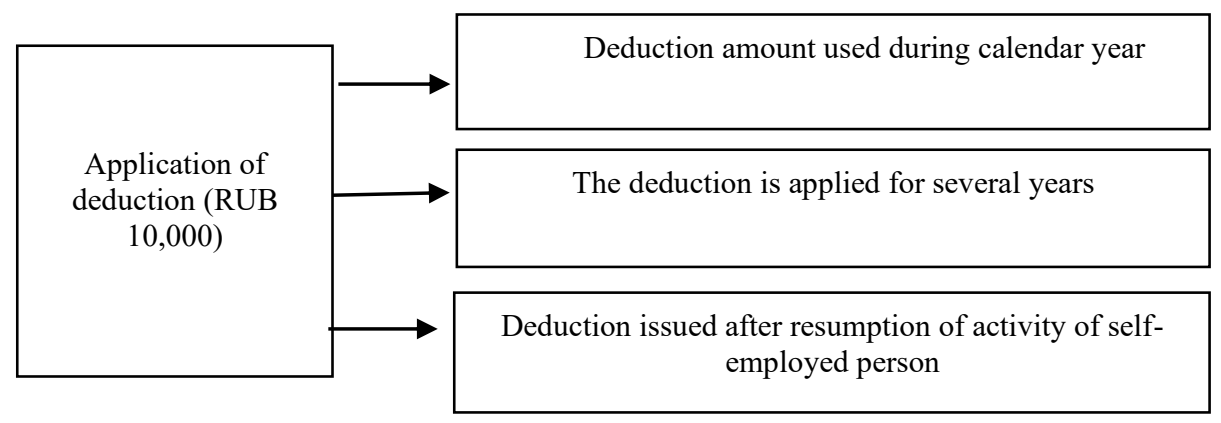

Fig. 2. Procedure for applying the deduction

To receive a tax deduction, you must send an electronic application to the Federal tax service via the mobile application "My tax". The Federal tax service, in turn, sends the taxpayer a corresponding notification, after which the deduction is taken into account when calculating tax. The tax service controls the deduction limit independently.

Noted that income for which an individual is a NAP payer is not subject to a personal income tax return. Recall that the deadline for providing a tax return on personal income tax for 2019 has been postponed by 3 months - to 30.07 .2020 , due to the difficult epidemiological situation [8].

Features of individual entrepreneurs transition to NAP application are given in Figure 3. 


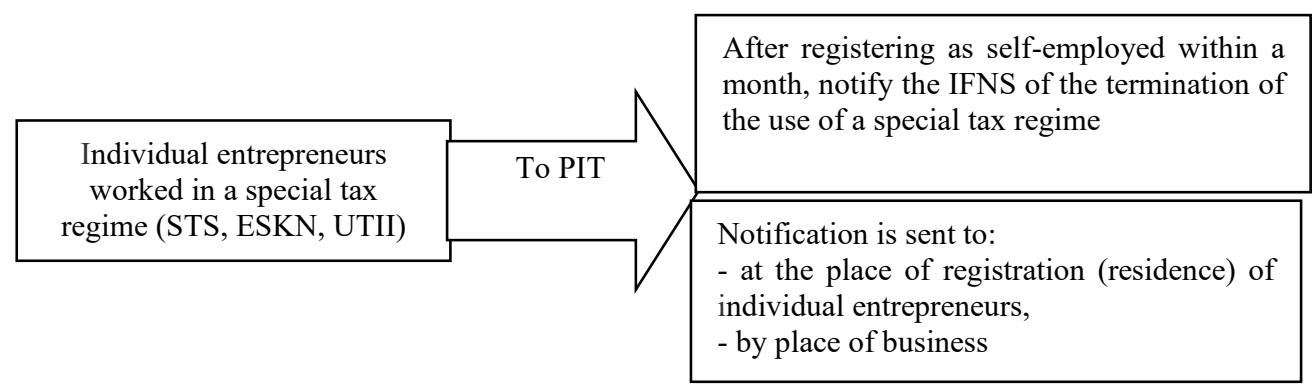

Fig. 3. Algorithm of individual entrepreneurs transition to PIT application

To register entrepreneur as a payer of the PIT is not cancelled, you must notify the tax authority at the place of registration (residence), SP, and all places of business. For example, it is necessary to inform the tax authorities about the refusal of the UTII in favor of the tax on the professional income of an individual entrepreneur at each point.

Please also note that after registering as a self-employed individual entrepreneur does not have to pay fixed insurance premiums, which were mandatory for them regardless of their business. In particular, in 2020, the amount of fixed insurance premiums for individual entrepreneurs is 40,874 rubles, of which

- $\quad 32,448$ rubles go to mandatory pension insurance (OPS);

- 8,426 rubles - the amount of contributions to compulsory medical insurance (MHI).

In our opinion, when working with the self-employed, the internal controller should develop an audit algorithm to reduce tax risks (Fig. 4)

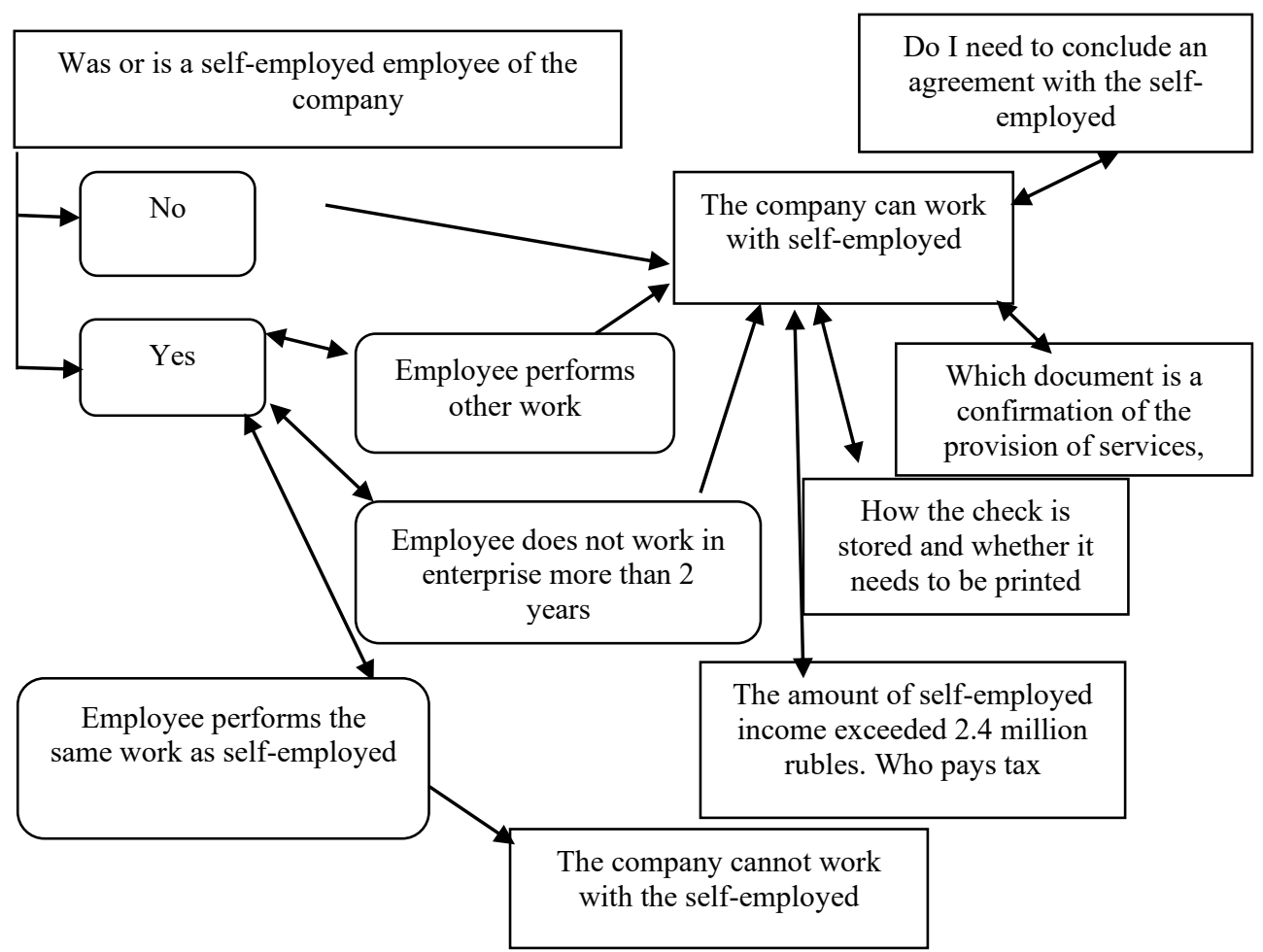

Fig. 4. Algorithm for checking the organization when working with the self-employed 
The internal controller should get answers to the questions that are reflected in the verification Algorithm shown in figure 4.

As follows from the presented Algorithm, starting to work with the self-employed, it is necessary to check whether the individual is an employee of the enterprise. The law allows the use of a special regime for self-employed individuals who have entered into an employment contract with a legal entity. However, such a legal entity for these individuals should not be the customer of services or works under the GPH agreement and should not be their employer less than two years ago. At least two years must have passed since the employee was dismissed. Thus, in order to save on paying insurance premiums and personal income tax, the organization will not be able to dismiss employees in order to enter into GPH contracts with them as self-employed [3].

On the need to contract with self-employed, you should consider that when providing services for the transaction performed immediately at the conclusion of the contract, a contract in writing is not required. The conclusion of the contract is confirmed by the payment of the corresponding amount to the customer for the services rendered. In accordance with the norms of the civil code unless otherwise provided by agreement of the parties may be concluded orally all trades executed by their commitment itself, with the exception of transactions for which notarial form is established and transactions the failure to comply with the simple written form of which entails their invalidity (item 2 of article 159 of the Civil code).

The next question that will arise for the internal controller is whether the amounts paid to the self-employed can be taken into account in expenses. Organizations and sole proprietors that apply OSNO and special tax regime, when calculating the tax base, have the right to take into account expenses for the purchase of goods, works or services from the self-employed (in accordance with the procedure established by law). The main document is a receipt generated by the self-employed using a mobile app. The terms of formation and transfer of receipts to the buyer (customer) are shown in table 4.

Table 4. Dates of formation of receipts sent to customers

\begin{tabular}{|l|l|}
\hline \multicolumn{1}{|c|}{ Situation } & \multicolumn{1}{|c|}{ Date } \\
\hline $\begin{array}{l}\text { Payment in cash and (or) using electronic } \\
\text { means of payment }\end{array}$ & At the time of settlement \\
\hline Other forms of cashless payments & $\begin{array}{l}\text { The receipt is generated and transmitted to the } \\
\text { buyer (customer) no later than the 9th day of the } \\
\text { month following the tax period in which the } \\
\text { calculations were made }\end{array}$ \\
\hline $\begin{array}{l}\text { Sale of goods (works, services, property } \\
\text { rights) on the basis of Commission } \\
\text { agreements, Commission agreements or } \\
\begin{array}{l}\text { Agency agreements with the participation of } \\
\text { an intermediary in favor of the taxpayer of } \\
\text { the PIT }\end{array}\end{array}$ & $\begin{array}{l}\text { The taxpayer does not generate a receipt to the } \\
\text { buyer for such transactions. The intermediary has } \\
\text { an obligation to use cash register equipment, if } \\
\text { legislation on the use of cash register equipment }\end{array}$ \\
\hline
\end{tabular}

The act may be an additional document reflecting the period or date of service provision for the purposes of tax accounting of the buyer's expenses, for example, if there is a prepayment. A receipt that can be sent to the buyer (customer) in electronic form or on paper, respectively, is mandatory for accounting expenses when determining the tax base, and the receipt can be stored both in electronic form and in printed form.

If a self-employed person who sold goods (works, services) to an organization or sole proprietor has lost the right to the PIT or its registration has been canceled, it is possible to accept the expenses already incurred for tax purposes until the documents confirming the transaction are issued. 


\section{Discussion}

From the date of loss of the right to apply the PIT, a legal entity is obligated to calculate and pay personal income tax and insurance premiums in respect of an individual who is not an individual entrepreneur. At the same time, there is no need to re-issue a previously concluded agreement between business entities, if this does not entail changes to the essential terms of the agreement.

For violation of tax legislation, the self-employed person may be charged the following fines:

- $20 \%$ of the amount for which the check was not issued, if the order or timing of the formation of fiscal checks is violated;

- if the violation is repeated within 6 months, the penalty will be charged in the amount of the entire settlement amount for which the receipt was not generated.

Noted that the tax authorities plan to pay close attention to self-employed citizens and businesses that try to use this special regime for illegal tax minimization. The Federal tax service will identify organizations and sole proprietors that actually hire self-employed people as employees without forming an employment relationship with them, and will charge them additional insurance premiums and personal income tax.

Using the presented algorithm, the internal controller will be able to take into account the main issues when working with the self-employed. However, it should be taken into account that the explanations of regulatory authorities appear systematically, and changes are also made to Federal law No. 422-FZ, so the Algorithm must be constantly updated. For example, farms using the verification algorithm presented by us will be able to take into account the restrictions provided for in regulations and sell their products with a lower tax burden. At the same time, organizations and individual entrepreneurs applying the general taxation regime, the STS or the Unified Agricultural Taxation, in the tax system, take into account the costs associated with the purchase of their own products from self-employed persons in the presence of a check.

\section{References}

1. Taxes and financial law, 12, 20 (2003)

2. N.V. Lutovinova, R.R. Lenkovskaya, G.N. Kuleshov, \& E.O. Tchinaryan, International Journal of Recent Technology and Engineering, 8(3), 7588-7591 (2019) doi:10.35940/ijrte.C6162.098319

3. Federal law No. 428-FZ of 15.12.2019 on amendments to the Federal law "On Conducting an Experiment to Establish a Special Tax Regime "Tax on Professional Income" in the City of Federal Significance Moscow, the Moscow and Kaluga Regions, and in the Republic of Tatarstan (Tatarstan)"

4. Federal law No. 101-FZ of 01.04.2020 "on amendments to article 1 of the Federal law" on conducting an experiment to establish a special tax regime " professional income Tax"

5. The number of self-employed people has increased in Russia, https://www.kommersant.ru/doc/4450113?query $=\% \mathrm{D} 0 \% \mathrm{BD} \% \mathrm{D} 0 \% \mathrm{~B} 0 \% \mathrm{D} 0 \% \mathrm{BB} \% \mathrm{D} 0$ $\% \mathrm{BE} \% \mathrm{D} 0 \% \mathrm{~B} 3$

6. Letter of the Federal tax service of Russia dated 18.11.2019 N SD-4-3/23424@ on the application of the special tax regime " Tax on Professional Income»

7. Letter of the Federal tax service of Russia dated 09.04.2020 N ED-20-20/45@ "On sending information» 
8. Letter of the Federal tax service of Russia dated 10.04.2020 N BS-4-11/6105@ "On taxation of personal income» 